\title{
Saint-Évremond, Écrits sur le théâtre
}

\section{Monica Pavesio}

\section{(2) OpenEdition}

\section{Journals}

\section{Edizione digitale}

URL: http://journals.openedition.org/studifrancesi/9945

DOI: 10.4000/studifrancesi.9945

ISSN: 2427-5856

\section{Editore}

Rosenberg \& Sellier

\section{Edizione cartacea}

Data di pubblicazione: 1 août 2017

Paginazione: 357

ISSN: 0039-2944

\section{Notizia bibliografica digitale}

Monica Pavesio, «Saint-Évremond, Écrits sur le théâtre», Studi Francesi [Online], 182 (LXI | II) | 2017,

online dal 01 août 2017, consultato il 11 janvier 2021. URL: http://journals.openedition.org/

studifrancesi/9945 ; DOI: https://doi.org/10.4000/studifrancesi.9945

\section{Questo documento è stato generato automaticamente il 11 janvier 2021.}

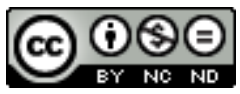

Studi Francesi è distribuita con Licenza Creative Commons Attribuzione - Non commerciale - Non opere derivate 4.0 Internazionale. 


\title{
Saint-Évremond, Écrits sur le théâtre
}

\author{
Monica Pavesio
}

\section{NOTIZIA}

SAINT-ÉVREMOND, Écrits sur le théâtre, Édition présentée, établie et annotée par F. Corradi, Pisa, Edizioni ETS, 2015, «L'écrivain critique», 108 pp.

1 Gli scritti di Saint-Évremond, nell'edizione annotata e presentata da F. Corradi, aprono la nuova collana del Seminario di filologia francese, intitolata L'écrivain critique. Nella ricca e approfondita introduzione, Corradi, dopo una breve presentazione biografica di Saint-Évremond, s'interroga sull'opportunità di inserire nella collezione una scelta di testi di uno scrittore che per primo si definisce «ni critique ni auteur». Quando SaintÉvremond scrive le suo opere critiche, il "campo" della critica letteraria è ancora instabile e privo di autonomia. L'Académie française, a partire dal 1635, ha il diritto di legiferare sulla poetica e di esprimere giudizi sulle opere, anche se il suo potere non è sempre riconosciuto ed origina alcune famose querelles. Gli strumenti a disposizione di Saint-Évremond per fare critica letteraria nascono proprio da queste querelles che imperversano nel panorama teatrale del XVII secolo.

2 Non esistendo ancora un metodo per scrivere critica letteraria, l'autore adotta un formato molto flessibile, che chiama "jugement", "lettre", "éloge", "dissertation", "observation". La frammentarietà e la totale indifferenza manifestata per la pubblicazione dei suoi scritti hanno portato al proliferare fin dal xvII secolo di edizioni non autorizzate e spesso apocrife. Solo all'inizio del xviII secolo, Saint-Évremond viene convinto a riordinare i suoi scritti e a curare un'edizione di qualità. La morte, purtroppo, gli impedirà di concludere l'impresa, ma i manoscritti da lui corretti saranno riuniti e daranno origine alla prima grande edizione pubblicata nel 1703 con il titolo di Euvres mélées, successivamente altre sue edizioni saranno pubblicate nel $1709 \mathrm{e}$ nel 1725.

3 Federico Corradi parte da questa prima edizione, e dal confronto con quelle successive, per regalarci un'edizione critica modernizzata e annotata degli scritti teorici di uno dei 
primi critici militanti della storia. Il volume comprende la Dissertation sur la tragédie de Racine intitulée Alexandre le Grand, i Quatre essais sur la tragédie et la comédie, le opere Sur les caractères des tragédies e De la tragédie ancienne et moderne e la Défense de quelques pièces de théâtre de M. Corneille. Si tratta di testi, scritti nel periodo compreso tra il 1667 e il 1677, in cui Saint-Évremond sviluppa i suoi punti di vista sugli autori antichi e moderni, francesi e stranieri, mettendo in luce, con grande insistenza, il suo disprezzo per la tragédie galante e la sua preferenza per Corneille rispetto al giovane rivale Racine, la cui stella sta offuscando ormai la gloria del rivale.

4 La bella edizione critica curata e annotata da F. Corradi, nonché l'approfondita introduzione, permettono la riscoperta di un autore troppo a lungo dimenticato e la ricostruzione di un periodo di grande importanza per lo sviluppo del teatro francese secentesco. 